Article

\title{
Let's Celebrate the Humane in the Humanities
}

\author{
Thomas Willard (D) \\ Department of English, University of Arizona, Tucson, AZ 85721, USA; willard@email.arizona.edu
}

Received: 23 July 2020; Accepted: 8 September 2020; Published: 10 September 2020

\begin{abstract}
The economic collapse in the U.S. during the Covid-19 pandemic has aggravated the problems caused by a generation of funding cuts to institutions of higher education and, with these cuts, the increasing costs for students and their families. The current problems raise anew the questions of what public good is created both by programs in the Humanities and by all forms of higher education. They are not new questions, but the responses often bring out the importance of humane education to a free society. Courses in the Humanities develop more than the skills in communication and critical thinking that employers say they value. Such courses contribute to the personal development, character formation, and emotional intelligence that create a healthy and productive society. The benefits of such education are considerable, but cannot be measured in a strictly business model of higher education such as is often used by institutions balancing budgets, as well as by the overseers to which they report, including regents, politicians, and community affiliates.
\end{abstract}

Keywords: higher education; university; college; tuition fees; general education; liberal education; vocational education; humane education; humanism; social contract; culture war; Socratic method; STEM; Covid-19; David Brooks; William Deresiewicz; Northrop Frye; John Locke; Thomas Jefferson

As I write, all the op-eds about higher education concern the novel coronavirus known as Covid-19. At public and private institutions, large and small, the big question is "If we reopen, will they come?" The implied secondary question is "If they come, what will happen?" A recent op-ed had the title "College Is Worth It, but Campus Isn't $t$ " (Dynarski 2020). Presented as an "economic view," it argued that "bringing millions of students back to campus would create enormous risks for society but little educational benefit."

There are further questions that American institutions have been asking for years, most urgently, "How can we survive in the current economy?" Over the past forty years, taxpayer dollars have decreased by one-half for public institutions, while tuition fees have increased at more than twice the overall inflation rate and wages for working adults have stagnated. Well before the current crisis, editorials pondered the cost-benefit relationship of higher education outside the elite institutions-those colleges and universities from which one researcher has shown "how elite students get elite jobs" (Rivera 2015). Meanwhile, the increased economic pressure on students and their families has led in recent decades to a rethinking of why students need or should seek higher education. One old assumption was that the bachelor's degree would pay for itself in lifetime earnings. Another assumption, at least as important for women as for men, was that college students would have the opportunity to live away from their places and families of origin for a time before entering the world of work and beginning families of their own - that they would have four years or so during which to make new friends from new backgrounds, to learn new ways of thinking about the big issues of life, and to discover passions they would carry into lifelong learning.

Sadly, many cost-benefit decisions being made in recent years involve the Humanities. In the month when I am writing, the University of Alaska system has announced the closing of nineteen academic programs at its three state universities, including creative writing, English, and theater. Meanwhile, the private Elmira College has announced the closing of programs in American Studies, 
Classical Studies, Spanish and Hispanic Studies, Philosophy, Religion, and Music (Dickler 2020). There is nothing new here, only the virus pandemic. Colleges and universities have been trying to balance budgets by cutting programs that make no measurable contribution to the state's or nation's economy. To some extent, the reduction of programs in the Humanities is a market-driven function: these programs are attracting fewer students and are not replacing tenured faculty as they retire or move elsewhere. The decisions about which programs to support or remove are also seen to be part of a culture war.

Shortly before news of Covid-19 was heard anywhere, the widely published columnist George Will began an essay by asking "whether higher education has not become a net subtraction from the nation's stock of reasonableness" (Will 2019). His major examples of that loss came from disciplines in the Humanities. He suggested that many professors in fields like English and History have a "mentality, stocked with stereotypes and luxuriating in victimhood," that repels young people who care about actual literature and history rather than critical reassessments in light of contemporary social theory. In a term he did not use, Will suggested that higher education has suffered during the "culture wars."

\section{American Education During the Culture Wars}

Discussion of culture war or wars has evolved considerably over the last century. The English term was first used in the late nineteenth century in articles about the conflict between church and state in countries where the separation was not written into a Constitution or another founding document. The term was later applied to struggles between neighboring cultural communities, such as the French and Flemish regions of Belgium. Only in the 1980s was the term applied to academic controversy. The controversy took place first between professors teaching courses very much as they had been taught in the recent past and others who subjected traditional course material to critical theory of various sorts-Marxists, Freudian, feminist, queer, etc. It then moved to controversy over the "canon," the classic texts of Western civilization or what the British poet and essayist Matthew Arnold once called "the best that has been thought and said in the world" (Arnold 1869, p. viii). Some Humanities professors wanted to "open the canon" to include texts by hitherto "marginalized" writers and thinkers; others wanted to replace the Great Books programs taught at many colleges and universities with courses featuring contemporary or at least recent figures such as Margaret Atwood, Derek Walcott, and Malcolm X. They clashed with the same people who insisted on the value of the old "Greats" courses, while they found fellowship with people in new departments of cultural studies, gender studies, and ethnic studies.

Several best-selling books came out of this phase in the culture wars. In The Closing of the American Mind, the American professor of philosophy Allan Bloom argued, in the words of his book's subtitle, that "higher education has failed democracy and impoverished the souls of today's students" (Bloom 1987). For him, the problem was a new relativism that made students open to all behaviors and beliefs, but also closed their minds to the possibility of holding definite beliefs for themselves and establishing the values that make a life worth living. In Cultural Literacy, E. D. Hirsch, an English professor with an interest in secondary education, argued that, despite all the variations in language and culture within the U.S., there were certain things "every American needs to know" (Hirsch 1987). A few years later, the late Harold Bloom maintained in The Western Canon that the literary canon was always open to receive new books of merit, which often built on their "precursors." The author spoke against the "school of resentment," which he thought placed too much value on the victims of history (Bloom 1990). Subsequently, Gerald Graff in Beyond the Culture Wars argued that "teaching the controversies can revitalize American education" (Graff 1993). The author, also a professor of literature and theory, wanted students to read classics of literature such as Huckleberry Finn from different perspectives. To this end, he encouraged reading critical essays developing both traditional and revolutionary interpretations. Students would then be asked to write thoughtful essays that drew from scholarship of both sorts to help develop their own interpretations. 
The first of these four authors lamented the demise of "critical thinking" among his students. The last wanted to promote it through exposure to the controversies. Although Graff focused on higher education, others have urged and reported on such an approach in secondary schools (Zimmerman and Robertson 2017). The rights of teachers to introduce controversial views have been debated in court and will continue to be debated. However, students introduced to the different sides in a court case or public debate can be allowed to read the opposing arguments without being obliged to decide as a court did in Colonial America or the Roaring Twenties, let alone to concur with the teacher's opinion. Courts of appeal have ruled that public school boards do not regulate speech so much as they hire the speakers (Steiner 2017).

In 2014, when the financial crisis of 2007-2009 had been reversed and the lost job numbers restored, reviews appeared of a challenging book about higher education in America, and especially in the elite universities that serve approximately $1 \%$ of all students seeking a bachelor's degree. The author was a fifty-year-old man with a PhD from Columbia University and a decade of experience as a teaching associate at Yale. He wrote about "the miseducation of the American elite" (Deresiewicz 2014), and his theme echoed that of the earlier book about "the closing of the American mind." He too was a product of the Great Books tradition, inaugurated at the University of Chicago, St. John's College, and other liberal arts institutions in the mid-twentieth century. ${ }^{1}$ But whereas the earlier writer was a neoconservative, the new critique came from a more liberal thinker who was even more concerned with the inability of even elite students to think critically and blamed the problem on the demise of substantial humanities requirements at their institutions.

Like Allan Bloom in 1987, William Deresiewicz in 2014 argued that liberal education means the education of free people. However, Deresiewicz wrote his book in the Tea Party era, when American society was more politically divided than it had been during the Reagan era. The term "culture wars" had become widely applied to the political divide in Washington, DC. The classical view that democracy depends on the existence of an educated electorate was open to debate. There were those who thought that elitism was the bane of populism, that scientists and other experts were not to be trusted when it came to determining public policy, and that the values children learn at home, school, and in places of worship were too often lost during the college experience. In a recent example, a college freshman tweeted her plea that young voters in her area not support her father's reelection to the state house of representatives. He, in turn, told a local television station: "When they go off to college, quite frankly they ... start getting indoctrinated with things that are completely polar opposite from where you raised them." The daughter had come to believe, with many of her generation, that the U.S. has a problem with systemic racism. The father thought, on the contrary, that the only racism occurred at abortion clinics, which, he said, were more likely to "target" women of color (Folley 2020; Noor 2020). ${ }^{2}$ Fortunately for the family, the father supported his daughter's choice of college and told the radio interviewer that he respected her right to free speech.

The conservative columnist David Brooks wrote a recent op-ed about the lack of presidential leadership during the Covid-19 pandemic. Here he begins by noting that past presidents have treated major crises like the Challenger explosion, Hurricane Katrina, and the school shootings at Sandy Hook as "something deeper than politics: They touch our sense of shared vulnerability and our profound and natural sympathy for one another." He notes that Abraham Lincoln turned to "biblical cadences" after Gettysburg and that Robert Kennedy quoted the Greek tragedy Agamemnon after the shooting of Martin Luther King, just a few weeks before he was assassinated himself. These leaders, Brooks says,

1 It is a notable irony that these Great Books programs grew directly out of workers' education programs in London and New York created before and after World War I; they grew only indirectly out of the undergraduate Greats program at Oxford, officially known as Literae Humaniores because it focused more on human subjects other than the those which made up the course of study for theology students.

2 The conservative case against Planned Parenthood rests in part on the claim that its founder, the nurse and socialist Margaret Sanger, was also a racist because she promoted eugenics. The argument has been examined and challenged with reference to Sanger's actual writings (Latson 2016). 
"were educated under a curriculum that put character formation at the absolute center of education" (Brooks 2020b; see Elmore 2009). President Trump has not released his college transcripts, so one cannot know what courses he took or how he performed in them.

The first American colleges were designed to train protestant ministers and servants of the local governments. Students were expected to come with a working knowledge of Latin, which continued to be a college entrance requirement into the 1950s. With their further Latin studies in college, they learned the ideals of classical civilizations, especially Rome's. Brooks notes that our current president "has no such resources to draw upon in a crisis." He does not suggest why that would not be the case for a president who graduated from a well-regarded university, why a university education today would not provide such historical and literary background, or how it might improve study in such areas. However, he makes one powerful point that deserves quotation in full:

Right now, science and the humanities should be in lock step: science producing vaccines, with the humanities stocking leaders and citizens with the capacities of resilience, care and collaboration until they come. But, instead, the humanities are in crisis at the exact moment history is revealing how vital moral formation really is. (Brooks 2020b)

Here one might quote Alberto Manguel, who has written extensively about the history of reading: "As Dante knew, literature is the most efficient instrument for learning compassion, because it helps the reader take part in the emotions of the characters." He offers this thought in his recent book Curiosity (Manguel 2016, p. 190), and we shall later find a more famous reader pressing the importance of curiosity to the character formation that Brooks urges (on the overlooked significance of character in higher education, see Albrecht Classen's introductory essay in this volume).

There is no point in having thoughtful and well-educated leaders, capable of reminding audiences about shared cultural values in times of need, if we do not have audiences capable of hearing a well-crafted message and appreciating its content. For this, certainly, a democracy has need of well-educated citizens. Civics classes are designed to give high school graduates the basic understanding they need to participate in the electoral system. They may not all have the knowledge or empathy to grasp a major speech, but there will be leaders to interpret the significance for them. In a small town, it may be the newspaper editor, the mayor, the local minister. I think of one such person.

I was a recent high school graduate when Martin Luther King, Jr. gave his famous "I have a dream" speech in August 1963. I was with my family in a small Vermont town when the March on Washington took place. We were assisting my elderly grandmother when I would rather have been at home in a suburb of Washington, DC, only a bus ride away from the crowds at the Lincoln Memorial. I planned to read the speech in the newspapers my father would buy the next day. But more than the words on paper I recall the sermon at the little Congregational church my grandmother attended all her life. The minister was new to the church, by his accent a transplant from the Midwest. He began by saying he was certain everyone had heard about the March on Washington. There may have been a few audible groans, but he quickly quieted them, saying that the Rev. King's speech was a very important one and that he wanted to say why it mattered. He had probably made his notes while listening to the speech on the radio or television, for he touched on one point after another about the shared values of Americans, from the Declaration of Independence to the Emancipation Proclamation, and beyond. All the points supported the theme that there was an unpaid debt long promised to the American Negro, full payment of which the Rev. King had a dream and benefits of which he as a minister could easily imagine for the United States and people like those in the congregation.

In the book mentioned earlier, William Deresiewicz uses the metaphor of the pupil as a sheep and refers to the Ivy League students he taught and discusses as "excellent sheep." They are "excellent" because they perform well for their herders, but the first two letters of "excellent" are crossed out with a big X on the dust jacket, as if to prepare for the book's emphasis on the students' "miseducation." When they graduate and take their places in the business and social elite, these students have the kind of "cultural literacy" that others saw lacking among many Americans in the late twentieth 
century (e.g., Hirsch 1987; see Bloom 1990). They know the simple details about American and world history and geography that have stumped students participating in some questionnaires and television interviews. They may know that Thomas Jefferson took the lead in writing the Declaration of Independence, but may never have considered the political thinking that went into his formulations. For example, the Declaration of Independence is based on the idea of the "social contract" advanced by Thomas Hobbes, John Locke, and Jean-Jacques Rousseau, among others. Jefferson knew their work very well, as did Benjamin Franklin, while the signers of the Declaration understood the principle that a king or other leader had a contract with the people of the nation (Hulliung 2007).

Locke maintained that people had the right to revolt against a government when it no longer worked in their interest (Locke 1690, sct. 194). It is therefore appropriate for citizens of a democratic society to discuss their social contract regularly. Sadly, however, proposals based on the idea of the social contract are often dismissed as un-American or socialist rather than debated on their merits. Indeed, the adjectives "socialist" and "socialized" are often used in the USA as they apply to economies elsewhere in the world such as the former Union of Soviet Socialist Republics (USSR) when, in fact, socialist principles were applied in the United States with temporary programs like the Work(s) Progress Administration (WPA) and long-lasting, still popular programs like Social Security and Medicare. The U.S. is therefore recognized as having a "mixed economy" rather than a purely capitalist or socialist one. The same economy that devotes part of its national wealth to help the poor also devotes a good part to assist corporations whose services are deemed essential—in both cases through direct transfers of funds as well as tax deductions. Locke trusted that a fair government would redistribute wealth fairly, and Jefferson saw unfair distribution, which took one group for granted, as a ground for revolution.

Professor Northrop Frye, at one time the most frequently quoted humanist writing in the English language, liked to extend the social contract to what he called "the educational contract." By this he understood "the area of free discussion in a society where the authority is not a social authority, or any kind of externally imposed authority, but the authority of the logical argument, the established fact, the repeatable experiment, and the compelling imagination" (Frye 2008, p. 152). In a discussion of Locke's essay on government, the authority in the room was neither the teacher or the editor of the text being studied; nor was it the group of students who prepared a PowerPoint presentation on the text. The authority was the text itself: what it said, what it left unsaid, and how it might be applied to the society within which the teacher and students lived. Frye's statement here was based on principles of classical liberalism, which could themselves be critiqued-and indeed corrupted in the much bemoaned Neo-Liberalism. However, it was his genuine attempt to overcome the implicit power relationship in the college classroom between the professor who assigns the grade and the student who needs to earn it.

\section{The Human and the Humane}

Due to the vagaries of pre-modern spelling, the English language has two versions of the word derived from Latin humanus. ${ }^{3}$ In medieval or Middle English, the human and the humane were the male and female of the species, counterparts of French humain and humaine. Approximately five hundred years ago, the two adjectives began to take on different overtones. The human was midway between the divine and the beastly, though it could take on characteristics of either in certain circumstances. The humane, meanwhile, was strictly concerned with human activity, but it referred to human behavior that was especially civil or benevolent. It also referred to studies that made people more civil. The second sense is the basis of our word "humanities," often written in the singular form in early centuries. England's champion of the "Advancement of Learning," Francis Bacon, referred to

3 Although I am naturally inclined to think about word origins in the language whose literature I have taught, I resort to the Oxford English Dictionary for its extensive history of English words. The second edition (20 volumes, 1989) is now being revised online to create a third edition (www.oed.com). 
"three knowledges: divinity, natural philosophy, and humane philosophy or humanity" (Bacon 1605). The honorary doctorate degree most often conferred at university convocations awards recipients the title Litterarum Humanorum Doctor or Doctor of Humane Letters.

Nevertheless, with books published before regularization of spelling in Modern English dictionaries like Samuel Johnson's and Noah Webster's, it can be difficult to know which version of the adjective was intended. John Locke's most famous book, An Essay Concerning Humane Understanding, first published in 1690 and so titled in all printings during the author's lifetime, is invariably printed and cited now as being concerned with "human understanding." Locke was a physician as well as a philosopher. He belonged to the Royal Society of London and shared a private passion for alchemy with fellow members Robert Boyle and Isaac Newton. He wrote books on government and education that greatly influenced the American Founding Fathers, among others, although his thoughts about the role of government in balancing the accumulation and distribution of wealth, a role crucial to education as he understood it, has been largely overlooked in recent years.

Locke's special significance for our discussion of education is that he places the highest value on curiosity, which he defines as "an appetite after knowledge." He considers it "the great instrument nature has provided to remove that ignorance they [children] were born with; and which, without this busy inquisitiveness, will make them dull and useless creatures" (Locke 1693). Locke was a former tutor and wrote for gentlemen with advice for preparing their sons to succeed them in their privileged social positions. However, he recognized that any visitor to a foreign country should ask the sort of questions that children naturally ask about the place where they were born. Just as he calls for parents and teachers to answer such questions fully and honestly, he expects adults to continue that curiosity in their daily lives. Here he concurs with Deresiewicz about the misfortune of students who, from admission to graduation, are encouraged to be competitive "hoop-jumpers" with the distant hope of landing high-paying jobs and to practice time-management with that goal in mind, putting no more effort into a course than is needed to earn the desired grade. Deresiewicz regards his book as a letter to his twenty-year-old self with the advice he could have used at that age: "The most practical thing you can do is to give yourself a real education where you learn not just to think, which is hard enough to learn in college, but how to make smart choices for yourself. How to find an inner compass, an inner sense of purpose because you know this is going to last you the rest of your life" (LaChance 2014; see Deresiewicz 2016).

Arguably, all academic disciplines concern human knowledge. Biology only creates human knowledge about the way animals behave inasmuch as they have instinctual or innate knowledge to guide them, as well as learned behaviors. Psychologists call this "naïve science" because non-human animals lack the language to formulate their understanding of how to navigate the world. Botany gives human knowledge of plant behavior, though work is far from finished about the genetics behind that behavior. Even divinity or theology, which was regarded as "queen of the sciences" (scientiarum regina) in the High Middle Ages (ca. 1000-1250 C.E.), and the first of Bacon's "three knowledges," is ultimately concerned with what humans can know about the divine during their mortal lives. Courses in the History of Religion and the Philosophy of Religion have followed religious texts and literature into the academic curriculum; so have courses in the History and Philosophy of Science. Just as I remain grateful to the minister who first led me through Martin Luther King's famous speech when I was all of eighteen, I owe a debt of gratitude to the visiting professor from the University of Allahabad who introduced me to Martin Buber's then recent book of lectures The Eclipse of God (1956) a few months later. Buber, in turn, introduced me to the differences between immanent and transcendent religion and convinced me that religion and philosophy need each other in the modern world (Buber 1956).

4 A search of the Google Books database shows that the plural version we now use, "the humanities," was rare before the nineteenth century, reached a peak in the 1960s, and has declined steadily since then. 
It would be good to revive the old linguistic connection between human and humane and as we think about the future of higher education, at least in the English-speaking world. The humane, so much the subject of courses in Humanities, is desirable as part of character formation in all education.

\section{Liberal and Vocational Education}

Around the turn of the last century, a distinction arose in the U.S. between the liberal arts education offered at older colleges and universities and the relatively new vocational education. In 1909, the year when the Lincoln-head cent was first minted, a popular magazine offered this advice: "Hard-pressed [i.e., less affluent] parents will make an effort to keep their children in training longer for the sake of the higher wages and greater opportunities for promotion offered by vocational education." At that time, the word "vocational" had been used in the popular press for more than a half-century. In 1846, the year when the first telegraph company was created, the newspaper of a small Ohio city reported on "agriculture, commerce, the mechanic arts, and other vocational pursuits," all of them concerning a person's source of income.

The term "vocational education" - now part of the more comprehensive "technical and vocational education and training" (TVET) — came as a great and necessary improvement on the older "servile education." The implication was that not all families had the wherewithal to send their children to receive education beyond that offered at the local public school, sometimes called the free school. Nevertheless, they shared the "American dream" that children would have opportunities not available to their parents: that they need not grow up to be servants, but should have some alternative to the "liberal education" available for a fee at the liberal arts institution, while children with no aptitude for Latin and the higher mathematics should also have access to post-secondary education. The terms "liberal" and "servile" had no political or philosophical overtones: they derived from the Latin artes liberales and artes serviles, from which comes the term "liberal arts." The last term is often expanded to "liberal arts and sciences" - for example, in publications of Phi Beta Kappa, the oldest liberal arts society in the U.S., to which many presidents and Supreme Court justices have belonged.

The artes serviles go back to democratic societies like Athens during the age of Pericles and Rome during its time as a republic, when the voting franchise extended to free citizens, but not to their slaves, servants, and providers of goods and services. The less socially conscious word "polytechnic" derived from French polytechnique and ultimately from the Greek adjective meaning "skilled in all arts." It was introduced in England in the nineteenth century and was introduced in the U.S. when the vocational school Throop College in Los Angeles shed its more scientific and "preparatory" courses with the formation of the California Institute of Technology, and the remaining courses became part of Throop Polytechnic. That institute has evolved into a private day school and college-preparatory institution called Polytechnic School or Poly.

Better known than the acronym TVET, mentioned above, is STEM (for science, technology, engineering, and mathematics). It was coined in the U.S. in the late twentieth century, though according to the Oxford English Dictionary (OED n.d.) it was rare before the year 2000. At first, the term "STEM" was used mainly for programs in public high school and such technical institutions as Cal Tech, M.I.T., and Rensselaer Polytechnic. But in the last two decades, almost all state universities have added the popular term, as have some private ones. Community colleges have also added STEM programs for students planning to go on to a four-year undergraduate program at a college or university. One obvious appeal of being a STEM university or a STEM college is that more grant money flows into the institution from those fields than from the liberal arts generally or the fine arts. Another is that those programs more clearly support the goal of "workforce development" advanced by the governing bodies of most public universities. They also support the "business model" favored by many of those governing bodies and the state legislatures to which many governing bodies report.

Of course, a STEM institute need not exclude all else. STEM universities may also be Hispanic-Serving Institutions (HSI) or minority-serving institutions such as Historically Black Colleges and Universities (HBCU). They may be land-grant institutions under the Morrill Act signed by 
Abraham Lincoln in 1862, though these colleges and universities were intended to concentrate on "agriculture and the mechanic [i.e., vocational] arts without excluding other scientific and classical studies, including military tactics" (Morrill 2009). A second Morrill act of 1890 provided for "the education of colored students in agriculture and the mechanic arts, however named and styled." Once again, "other scientific and classical studies" were to be included, as well as "military tactics." The design of the Morrill Act was to help states educate their populations, with the focus on those who were headed into labor as opposed to the traditional learned professions (law, medicine, and the ministry). Tuition rates at land-grant institutions were typically much lower than those at elite private colleges. The Constitution of the state of Arizona, written in 1912 when the only university was the land-grant institution, states: "The university and all other state educational institutions shall be open to students of both sexes, and the instruction furnished shall be as nearly free as possible" (Art. IX, sec. 6; italics added). Though many revisions to this constitution have been proposed, and legislators have often spoken about the valuable experience of taking out a student loan and paying it back, no one to my knowledge has proposed removing the second, italicized clause. Legislators have found it increasingly important to fund the creation of prisons, especially private prisons. When I moved to Arizona in the 1970s, the state spent twice as much on education as it did on prisons. Now it spends half as much.

I am often asked if I have seen changes in my students over the years. I began to be asked this question by neighbors outside the university, but also by parents, former students, and members of the business community with whom I had contact. My answer would usually surprise them, for they probably expected me to address the level of literacy I encountered. Had it improved or declined? Instead, I spoke about the students' lives outside the classroom. My first-day questionnaires always asked whether they would be holding down a job during the new semester and, if so, where and for how many hours a week. This was where the big change occurred. In my first years at the university, most students with jobs worked on campus, as part of a financial assistance plan that typically required ten hours of work each week. Their employers were usually sensitive to their needs, perhaps to attend a recommended lecture or review session or another event on campus. Before long, I was hearing of jobs off campus that required changes in their schedules. In my last years, as tuitions and living expenses rose, I had students working full time while taking a full load of classes. Many were under pressure from home to graduate as soon as possible. Many had younger siblings at home and parents struggling to make the tuition payments that were always increasing. I felt badly for such students, both as a teacher and as an academic advisor, because I knew they often did not have the opportunity to explore new ideas or participate in the extracurricular activities for which the college is often valued. Meanwhile, students who are not working are often taking on staggering debt. These are social problems that an institution cannot solve by using a data-driven "business model". To a large extent, they are political problems.

I have seen the limits of the business model during years of service on committees concerned with undergraduate education at my university, and especially with the "general education" courses designed to add breadth to the depth of coursework in a student's major. Two ongoing debates struck me as the least soluble. The first concerned course content. Would students have a set plan designed by their major department or college, or would they all have the same set of general education requirements? Moreover, would they have a set curriculum with a limited number of courses, or would they have "cafeteria" style offerings from which to choose-for example, a course devoted to the later dialogues of Plato as opposed to one in Classical Humanities? With the first question, faculty members have grudgingly recognized that many undergraduates change their major subjects at least once. With the second question, they have been less prepared to give up their academic freedom. They might agree that a college student should learn about Science, the Social Sciences, or the Humanities in order to become an informed member of society. However, they also knew what they themselves wanted to teach and indeed what they were willing to teach. The result was that no one was satisfied, including 
students surveyed before they graduated. General Education programs tend to be recreated once every decade, and I have heard that the current committee is facing the same questions.

The second debate tends to arise outside the Humanities, while hoping the Humanities will take up the burden. Professors agree about the importance of writing and communication, including those skills within their disciplines. However, many resist the requirement of writing assignments on which students receive feedback and are asked to revise their work. This seems to be the task for language and speech departments. They also agree about the importance of developing critical thinking skills, which are closely tied to writing, but claim that they must deliver facts needed to pass national examinations such as the Medical College Admission Test (MCAT) or Graduate Record Examinations (GRE) in their students' disciplines, both of which have multiple-choice questions. Despite the growing body of evidence that students often learn more about a discipline when they must read articles in the popular press and respond to questions raised there, professors and especially department administrators are reluctant to focus on the different needs of those students fulfilling a distribution requirement in their field and those of their own beginning majors. The resistance is often cited as sheer necessity. Especially in Engineering, but also in other STEM subjects, they must meet the requirements set forth by the bodies that certify their programs. They must depend on the basic requirements in the Humanities departments, including composition and foreign language acquisition, to provide the students with the knowledge of grammar that they themselves acquired in secondary school or college and to learn how to read, interpret, and evaluate texts both literary and nonliterary. Meanwhile, they know that university administrators prefer to see courses with large enrollments rather than the necessarily smaller courses in composition or the basics of a foreign language and culture.

When considering the range of academic programs available in the future, educators and politicians naturally take into account the changing nature of the workforce. It is rare for people entering the job market to spend the rest of their productive years with the same employer or even in the same line of work. Statistics suggest that, on average, Americans change jobs ten to fifteen times during their working years (Bureau of Labor Statistics 2019). Workers who will be better off are those who have that "inner compass, an inner sense of purpose" that as Deresiewicz says a good education can provide (LaChance 2014). This, too, suggests the need for humane education-education that regards the student not as a customer, but as a fellow citizen.

\section{Humane Education in the Future}

The torching of Humanities programs and their removal from college catalogues is not inevitable. Indeed, it can be remedied, but that will require a conversation that goes beyond the varied institutions of higher education to include such desiderata as character formation. The National Endowment for the Humanities, established in 1965, has a budget of $\$ 162$ million for the year 2020, compared to the $\$ 8.3$ billion for the National Science Foundation, which grew out of investments in military research and development during World War II. Philosophers studying the development of thought in Europe and China will not have the funding of aerospace engineers planning the next visit to Mars, and are therefore unlikely to figure so importantly in their institutions' publicity and fundraising. Nevertheless, they may have equal impact on the mental and moral development of their students.

Courses using the Socratic method of inquiry into the writings of Shakespeare, Cervantes, or indeed Plato are unlikely to turn a profit. Their enrollments are limited out of necessity. It is not unusual for faculty members serving on undergraduate education committees to debate the minimum or maximum numbers of students in a course, with the scientist urging a minimum of 100 while the humanist insists on a maximum of 25. The larger class size has a strong appeal for those who must balance budgets using the arcane formulas of Responsibility-Centered Management and other popular business models.

The coronavirus pandemic has raised larger questions than the future of higher education. The questions that the college freshman encountered before tweeting, "Don't vote for my dad," included fundamental ones about the future. If a vaccine for Covid-19 becomes available, how will the 
supply meet the demand? In a laissez-faire or free market economic model, increased demand will increase the price, and increased price will increase the supply. Those who can afford the product will obtain it, while those who cannot must fend for themselves. In a true market economy such as still exists in some third-world and emerging countries, the affluent must also arrange for their own protection against crime and foreign enemies. In the United States, this model ceased with the world wars and financial recessions of the last century. It became necessary to introduce elements of a socialized economy creating what economists have long called a mixed economy.

During the first decades after World War II, institutions of higher learning grew with government support in many forms, from the G.I. Bill for returning soldiers and Fulbright Scholarships for outstanding students to study overseas to the Pell Grants of recent years. Much of the new funding came from the Federal government, but was once matched in the states that benefitted most from having a well-educated population. Then came a political revolution that blamed the country's woes on big government, giving a pass to big business and financial institutions that were too big to fail. This century's first big pandemic has put extra economic pressure on many parts of American society, including its higher education. It seems obvious that many universities, colleges, and community college campuses will not survive. Just how many will survive is a question that only voters can answer. They can survive for the good of the affluent family or the good of the country. They can survive by offering a traditional range of learning or primarily vocational courses. The choices will be financial ones under the current modes of accounting — modes that ask how much a college must spend per student credit hour in Business, Education, Humanities, and other disciplines. Here the social contract comes into question. Should higher education be made free for most institutions and families, as some have argued (e.g., Potter 2020)? Should student debt be limited, as past administrations have tried to do? Could the U.S. limit the cost of higher education, as most advanced countries have done, even if that means a shift of public spending priorities or an increase in the tax rates for certain groups of people and corporations?

It has been almost two centuries now since the French diplomat Alexis de Tocqueville made his tour of our new country and wrote his classic study, Democracy in America. He included a chapter explaining "why the study of Greek and Latin literature is particularly useful in democratic societies" (Tocqueville [1835] 2000, chp. 15, pp. 450-52). He recognized that democracy was quite different in America than it had been in Athens, where only the aristocrats could vote, or in Rome under its long-lived republic, where wealthier plebeians offset the aristocrats. All of these male voters could be trained in rhetoric, politics, and history. Their surviving speeches and other writings showed ideas and eloquence still valuable to those who governed. In the American democracy, it seemed obvious that the masses of people, the "middle class" that provided the services performed by the more successful Roman plebeians, needed education that was "scientific, commercial, and industrial rather than literary." They did not need the classics, but "those whose natures [aptitudes] or whose fortunes destines them to cultivate letters" could do no better than to study what we call the Humanities. These people were not only the counterparts of Roman patricians, but included Americans who aspired to leadership. De Tocqueville did not think any serious writing was "irreproachable." He only urged that what we call the Humanities "have special qualities that can serve marvelously to counterbalance our particular defects," by which he meant the narrow focuses of a given time. He continued, "They prop us up on the side where we lean," that is to say, where we falter.

Northrop Frye formed his concept of the "educational contract," mentioned earlier, during the post-World-War-II era in Canada, when the social contract itself was fairly secure and government support of education seemed ensured for at least the near future. I was fortunate enough to be his graduate student, under his advising, and my tuition costs as a foreign student were, to quote again from my state's constitution, "as nearly free as possible." I had the freedom to devote myself to full-time study that few of my own graduate students have had in recent years. To be sure, Frye would occasionally grumble about what he called "the perpetual crisis in the Humanities," especially during his years of service as Vice President and then President of the Modern Language Association (MLA) 
during the late 1970s. By "perpetual" he meant not only the increasing job crisis for new PhDs, but the age-old fate of the Humanist that afflicted people like John Locke in seventeenth-century England as much as the Italian Humanist Lorenzo Valla in the early fifteenth century and even members of the Platonic Academy as it existed, off and on, into the sixth century C.E. Frye died in 1991, so he did not live to see the results of governments' underfunding of public education during the last of his five decades of teaching. As a former college president and university chancellor, he would have cringed to see the book Academia, Inc.: How Corporatization Is Transforming Canadian Universities (Brownlee 2016; also see Carey 2019). I suspect that such a book would have made him think about Locke's social contract, for Locke wrote that when a government ceases to support its constituency, "then all free and voluntary contracts cease" (Locke 1690, sct. 194). Locke then asked, "[C]an there be anything more ridiculous than to say [i.e., as a monarch], I give you and yours this forever, and that in the surest and most solemn way of conveyance that can be devised; and yet it is to be understood, that I have the right, if I please, to take it away from you again tomorrow?"

Editorials today still refer to higher education generally as "the academy," using the term that Plato applied to his own school for the sons of the Athenian aristocracy. Plato called the education offered at his Academy "paideia" (pronounced PIE-day-ah). By this he referred to the education needed to sustain the Athenian state, the polis from which we get our words for "politics" and "policy." It requires a balance of education in both the verbal arts (grammar, logic, rhetoric, and philosophy) and the practical ones, including mathematics, medicine, music, and military science. Plato's view of education was summed up in a statement in book 4 of his Republic, where Socrates answers questions about the education that is best for a republic: "fine things are difficult" (Plato 1961, p. 677; Republic 435c). Elsewhere in the Republic, among his last major dialogues, Plato suggests that education should include an element of entertainment, which literature and the fine arts provide (Plato 1961, p. 1256, Laws 659d).

The famous Socratic method of teaching - the dialogue of student and teacher in the pursuit of truth-involves what educators now call critical thinking. Critical thinking, in turn, is part of Frye's educational contract, in which both student and teacher accept that there is an authority higher than either of them-higher than the personal opinion that is so basic to being human. This occurs in Plato's dialogues when Socrates says his famous "I know nothing" and invites the students to reason with him about what they think they know. As he put it in his apology to the court of Athens, "I know that I know nothing" (Plato 1961, Apology 21d). From this humble beginning comes a hard-earned realization: "I may be wrong." And until that point is reached, our personal discussions are mere opinion, while public discourse in our time of Covid-19 remains just as polarized. Indeed, as a prominent British historian has said, it verges on "mass infantilization" (Doyle 2020). The Victorian thinker Herbert Spencer stated at the start of his book First Principles that there is "a soul of truth in things erroneous" (Spencer 1863, p. 3). This is a worthy principle for all scholarship: not to dismiss arguments as being "false" but to understand their truth as well as their falsehood. In the word of the credit-card commercial that tries to put a price on everything one may need, this openness to other people's ideas is "priceless." It does not fit the business model of education. But it certainly helps to resolve tensions in society. People cannot learn from their mistakes who do not first recognize them as mistakes they made.

Of course, Socrates was not welcomed by all Athenians. He was put on trial in 399 BCE, charged with corrupting the young who listened to him, notably by discouraging literal belief in the city gods. Because at least two of his protégés were associated with the previous government, their names would have been sufficient evidence for many. We cannot expect Plato to sort out American education today, any more than we could expect de Tocqueville to work the charm. But their writings, when studied by students who are properly introduced to them and given the opportunity to discuss the issues, can prepare for the sort of evaluation that was going on at historic moments in our country's history-in Philadelphia in July of 1776, when the Second Continental Congress drafted the Declaration of Independence, or in Williamsburg, Virginia, in December of that year, when the Phi Beta Kappa 
society was formed to promote free private debate of difficult social questions like the abolition of slavery.

Discussions of this sort are basic to courses in the Humanities. Speaking to an interviewer curious about his critique of miseducation at Yale and other elite institutions, Deresiewicz said, "Studying the humanities is a politically significant act." He added, "What's at stake is not just individual opportunity or national prosperity, although both of those are. What's at stake finally is our political liberty" (quoted in Silverstein 2016). The open discussion of ideas that shaped what became the United States is exactly what leads to the character formation that David Brooks sees as being necessary to effective and inclusive government (Brooks 2020b). "Liberal education" and "Liberal Arts education" may be the wrong terms for this kind of education in a politically polarized society. "Humane education" might be better, since few people wish to be inhumane in their private lives. Even then, it would face the old resistance that put "divine knowledge" above human knowledge, because it is based on revelation to be taken as a matter of faith rather than of knowledge gained through human experience, with all the necessary searches and discoveries. To be sure, the nineteenth-century association of humanism and atheism, captured in the term "secular humanism," is often used to dismiss scientific theories that seem to contradict biblical teachings. But long before the secular humanists, going back to the Italian Renaissance of the fifteenth century, there have been scholars who identified as Christian humanists-scholars whose work has the spark of religious insight that made it truly humane. C. S. Lewis, a great scholar and teacher as well as a Christian apologist, identified with the tradition of Christian humanism, as did the other members of the Oxford group of writers who called themselves the Inklings (Butynskyi 2020; see Brian Mucdoch's contribution to this issue).

To speak of Humane Education today would restore the Humanities to a central place in higher education, along with Science and Technology, Engineering and Mathematics, and even military tactics. It could make teachers and administrators at public institutions more conscious of the public they serve, and those at private institutions think more often about the organizations, religious or other, that are part of their academies' histories. It could promote the free discussion of ideas that would get beyond partisanship as a priority. As Brooks has written in a follow-up essay, this "may be what radical centrism looks like" - as opposed to the much-demonized views of the "radical left" and "far right" (Brooks 2020a). Funding will remain the big problem of higher education in the United States, at least until major decisions are made about the relationship of citizens, governments, and the various institutions of learning. But I suspect and hope that some form of what I have called "humane education" will reinsert itself in all degree programs. For the humane element will help to shape not only the workforce of the future but also the engaged citizenry that makes a country work.

Funding: This research received no external funding.

Conflicts of Interest: The author declares no conflict of interest.

\section{References}

Arnold, Matthew. 1869. Culture and Anarchy: An Essay in Political and Social Criticism. London: Thomas Arnold and Sons.

Bacon, Francis. 1605. The Two Books of the Proficiency and Advancement of Learning. London: Henry Tomes.

Bloom, Allan. 1987. The Closing of the American Mind: How Higher Education Has Failed Democracy and Impoverished the Minds of Today's Students. New York: Simon and Schuster.

Bloom, Harold. 1990. The Western Cannon: The Books and School of the Ages. New York: Harcourt Brace.

Brooks, David. 2020a. President Biden's First Day: Imagining Jan. 20, 2021. The New York Times. July 16. Available online: https://www.nytimes.com/2020/07/16/opinion/biden-2020.html?action=click\&module=Opinion\& pgtype=Homepage (accessed on 1 August 2020).

Brooks, David. 2020b. "If We Had a Real Leader." Covid Under a Real President.". The New York Times. May 29, p. 27. Available online: https://www.nytimes.com/2020/05/28/opinion/coronavirus-trump.html?action= click\&module=Opinion\&pgtype=Homepage (accessed on 30 June 2020). 
Brownlee, Jamie. 2016. Academia, Inc.: How Corporatization Is Transforming Canadian Universities. Black Point and Winnipeg: Fernwood Publishing.

Buber, Martin. 1956. The Eclipse of God: Studies in the Relation between Religion and Philosophy. New York: Harper \& Brothers. Bureau of Labor Statistics. 2019. Occupational Outlook Handbook. Lanham: Berman Press.

Butynskyi, Christopher. 2020. The Inklings, the Victorians, and the Moderns: Reconciling Tradition in the Modern Age. Vancouver, Madison and Teaneck: Fairleigh Dickinson University Press.

Carey, Kevin. 2019. The Creeping Capitalist Takeover of Higher Education. The Huffington Post. April 1. Available online: https://www.huffpost.com/highline/article/capitalisttakeover-college/?guccounter=1\&guce_referrer=aHR0cHM6Ly93d3cuZ29vZ2xlLmNvbS8\&guce_ referrer_sig=AQAAAIqI86rKTmvoOjRvbcv8w8T15ALnWS6A9W6nuC7Oi-Psv9w8-pE8GxayzKbTptjoE02dnB7G0brOvOBb1WsAdUtyS13JLItgDDK5x2G6Gx8JecWGIDVYsvVhoBSjMIthl0GdLm4WRCMEniQTx0MykxDKWTOd4-aoX2iGQIeMxt (accessed on 2 August 2020).

Deresiewicz, William. 2014. Excellent Sheep: The Miseducation of the American Elite and the Way to a Meaningful Life. New York: Free Press.

Deresiewicz. 2016. TED@MtHood. Available online: https://www.ted.com/tedx/events/16542 (accessed on 1 July 2020).

Dickler, Jessica. 2020. Colleges Cut Academic Programs in the Face of Budget Shortfalls Due to Covid-19. CNBC. June 23. Available online: https://www.cnbc.com/2020/06/23/colleges-cut-programs-in-face-of-budgetshortfalls-due-to-covid-19.html (accessed on 1 July 2020).

Doyle, Andrew. 2020. The Mark of an Educated Mind. Standpoint. May/June. Available online: $\quad$ https://standpointmag.co.uk/issues/may-june-2020/the-mark-of-an-educated-mind/?fbclid= IwAR25Q1rlakYc9quiVbTUwqkIXz1tJq8EAvPH19innHOP4T1c3vcEAWqiliA (accessed on 4 August 2020).

Dynarski, Susan. 2020. College Is Worth It, But Campus Isn't. The New York Times. June 29. Available online: https://www.nytimes.com/2020/06/29/business/college-campus-coronavirus-danger.html (accessed on 30 June 2020).

Elmore, A. E. 2009. Lincoln's Gettysburg Address: Echoes of the Bible and the Book of Common Prayer. Carbondle: Southern Illinois University Press.

Folley, Aris. 2020. Michigan candidate's daughter urges people not to vote for him in viral tweet. The Hill, June 25.

Frye, Northrop. 2008. Interviews with Northrop Frye. Edited by Jean O'Grady. Toronto: University of Toronto Press.

Graff, Gerald. 1993. Beyond the Culture Wars: How Teaching the Controversies Can. Revitalize American Education. New York: W. W. Norton.

Hirsch, Eric D. 1987. Cultural Literacy: What Every American Needs to Know. Boston: Houghton Mifflin.

Hulliung, Mark. 2007. The Social Contract in America: From the Revolution to the Present Age. Lawrence: University Press of Kansas.

LaChance, Naomi. 2014. Defining a Real Education. U.S. News \& World Report, August 22, 17-18.

Latson, Jennifer. 2016. What Margaret Sanger Really Said about Eugenics and Race. Time. October 14. Available online: https://time.com/4081760/margaret-sanger-history-eugenics/ (accessed on 7 July 2020).

Locke, John. 1690. An. Essay Concerning the True Original, Existence and End of Civil. Government in Two Treatises of Government.. London: Awnsham Churchill.

Locke, John. 1693. Some Thoughts Concerning Education. London: A. and J. Churchill.

Manguel, Alberto. 2016. Curiosity. New Haven: Yale University Press.

Morrill, Justin Smith. 2009. First and Second Morrill Act (1862 and 1890). Available online: https://nifa.usda.gov/ sites/default/files/asset/document/First\%20and\%20Second\%20Morrill\%20Act.pdf (accessed on 15 July 2020).

Noor, Poppy. 2020. 'Please for the love of God don't vote for my father': Republican's daughter voices opposition. The Guardian. June 26. Available online: https://www.theguardian.com/us-news/2020/jun/26/please-do-notvote-for-my-dad-republican-daughter-robert-reagan-michigan (accessed on 15 July 2020).

Oxford English Dictionary. n.d. Available online: www.oed.com (accessed on 6 July 2020).

Plato. 1961. The Collected Dialogues, Including the Letters. Edited by Edith Hamilton and Huntington Cairns. Princeton: Princeton University Press.

Potter, Clare Bond. 2020. The Only Way to Save Higher Education Is to Make It Free. The New York Times. June 5. Available online: https:/www.nytimes.com/2020/06/05/opinion/sunday/free-college-tuition-coronavirus. html?searchResultPosition=2 (accessed on 30 June 2020).

Rivera, Lauren A. 2015. How Elite Students Get Elite Jobs. Princeton: Princeton University Press. 
Silverstein, Hannah. 2016. 'Excellent Sheep' Author to Speak in Defense of Humanities. Dartmouth News. October 28. Available online: https://news.dartmouth.edu/news/2016/10/excellent-sheep-author-speak-defensehumanities\#: \{\}:text=1\%20talk\%2C\%20William\%20Deresiewicz\%20will, the \%20humanities\%20are \% 20for\%20veryone.\&text=Studying\%20the\%20humanities $\% 20$ is $\% 20$ a,Way $\% 20$ to $\% 20$ a $\% 20$ Meaningful $\%$ 20Life (accessed on 6 July 2020).

Spencer, Herbert. 1863. First Principles. London: Williams and Norgate.

Steiner, David. 2017. On Teaching Controversy: The Role of Lively Debate in the Classroom. Education Next 17: 79-80.

Tocqueville, Alexis de. 2000. Democracy in America. Translated and Edited by Harvey C. Mansfield, and Delba Winthrop. Chicago: University of Chicago Press. First published 1835.

Will, George. 2019. Humanities Departments Have Necome a Net Subtraction from Reasonableness. Albany Democrat-Herald. November 13. Available online: https://democratherald.com/george-will-humanitiesdepartments-have-become-a-net-subtraction-from-reasonableness/article_c0240979-76bb-5fb5-9bb29f74d8b49bdd.html (accessed on 28 June 2020).

Zimmerman, Jonathan, and Emily Robertson. 2017. The Case for Contention: Teaching Controversial Issues in Amemrican Schools. Chicago: University of Chicago Press.

(C) 2020 by the author. Licensee MDPI, Basel, Switzerland. This article is an open access article distributed under the terms and conditions of the Creative Commons Attribution (CC BY) license (http://creativecommons.org/licenses/by/4.0/). 